DOI https://doi.org/10.18551/rjoas.2017-01.11

\title{
EXPANDING HEALTH TOURISM IN INDONESIA: PROSPECTIVE SHARIA SALONS AND SPAS
}

\author{
Bafadhal Aniesa Samira \\ Faculty of Administrative Science, University of Brawijaya, Indonesia \\ E-mail: aniesa.bafadhal@ub.ac.id
}

\begin{abstract}
Currently, health issues have grown rapidly into Health Tourism segment to strengthen Indonesia's tourism. Ironically, the proliferation of salon and spa business as well as other forms of health tourism business is considered to cause negative effects in the form of destructive cultural penetration of foreign tourists. This study aimed to analyze the prospects of sharia salons and spas in safeguarding the health tourism in Indonesia. Furthermore, we examine the mix variables of sharia marketing as a marketing stimulus to encourage Muslim tourists in making the decision to visit and re-visit as well as their interest in the sharia salons and spas. This explanatory study uses the paradigm of quantitative research involved 150 respondents of Muslim tourists and domestic visitors of sharia salons and spas in Malang, Indonesia. The results of this study indicate that stimulus of sharia marketing is needed to develop tourist visits, especially Muslim travelers in health tourism destination of sharia salons and spas.
\end{abstract}

\section{KEY WORDS}

Health tourism, Sharia salons and spas, Muslim tourists, Sharia marketing, Indonesia.

Thousands of years ago, people had to travel to distant places in order to heal themselves, so essentially a medical tourism is a phenomenon that has long existed. In its development, global competition has emerged in the health care industry. Countries that have advanced the tourism, such as Switzerland, Germany, France, UK, USA, Canada, Austria, Australia, Japan, China, Singapore, and even Malaysia have long organized forms of such health tourism for both domestic tourists and foreign tourists. This then led to the term of borderless patient for health tourists in developed countries and in developing countries. Wealthy patients from developing countries have long traveled to the developed countries for high-quality medical care. However, now many middle economic class patients from developed countries travel to developing countries to seek high quality medical care at affordable prices (Herrick, 2007).

Currently, health issues have grown rapidly into Health Tourism segment to strengthen tourism, not least for Indonesia, which has a lot of local knowledge in the field of health from the science of alternative medicine heritage. Health tourism activity generally refers to patients who travel for beauty, rehabilitation, care of themselves in their recreation. Health tourism emerged as a new form for the tourism industry which is diffusion between the needs of an individual to obtain health care and their wish to travel in the same time (Rollyson, 2010; Munro, 2012; Snyder et al., 2013; Henema, 2014). The form of implementation of health tourism includes yoga, gym or fitness, dentistry, spiritual festivals, ayurveda, mud baths, cosmetic surgery, acupuncture and acupressure, and what has been popular in Indonesia is a salon and spa services business.

Tilaar (2011) state that the development of salon and spa in Indonesia and the world is growing rapidly. Factors causing the inner pressure or stress are increasingly high that many people, especially among metropolitan, require salon and spa as a means of treatment for relaxing theraphy. Ironically, the development of health tourism in Indonesia also poses the threat of penetration of "wild west" (Macready, 2007; Cortez, 2008; Johnston et al, 2010) brought by foreign tourists as foreign culture can lead to transformation of culture or even cultural amnesia, that will ultimately bring multiple effects on various sectors of public life and business industry. 
Young (1973) suggests that tourism may give rise to an undesirable activity, such as prostitution, sex trafficking, and HIV and penetration of foreign culture that can have negative impacts for local communities. In public perception, spa and salon business is identical to the negative stigma (Narendran, 2011). This is evidenced by the emergence of 'plus-plus' salon and spa, erotic massage parlors, homosexual salon as well as prostitution under the guise of health and fitness business in Indonesia. Although it promotes itself as a spa and sauna with exclusive prices and services, in practice it is similar to prostitution and other hedonism.

The mindset of tourism businesses people tend to be oriented to economic advantages alone without strong commitment and awareness in maintaining cultural, social, and religious values; and this can be a threat to the nation and especially for the development of the tourism industry itself. On the other hand, Indonesia is a potential market of abundance domestic Muslim tourists. However, the limited variety of facilities and infrastructure of the health tourism and ethical fulfillment of sharia and affluence of 'plus-plus' spa and salon in Indonesia shows that the country is still weak in capturing the opportunities and potential of Muslim tourists even for domestic market needs.

On a variety of spa and salon areas in Indonesia, it is difficult to obtain standard service according to the value of sharia for Muslim women who keep the "aurat" according to the religious beliefs, for example in terms of a therapist of the same sex, no-pork raw materials, no eyebrow shaving or like-man hair, and so forth.

Recognizing the potential and opportunities of Muslim tourists, and keeping the noble values of the nation's culture as well as maintaining and increasing attraction for them, both domestic and foreign tourists, on health tourism in Indonesia, the Ministry of Tourism and Creative Economy has started to promote standardization of sharia spa and salon (Ministry of Tourism, 2015).

Sharia salons and spas is a model of spas and salons that offer beauty therapist and rooms based on gender, halal cosmetic materials as well as service, interior, equipment and other facilities that comply with Islamic law (Yemen et al., 2012). Sharia salons and spas is expected to minimize the practice of adultery and other hedonism. Sharia salons and spas business continues to grow and is proven profitable and some has been using a franchise system. Until now, there are about less than a hundred sharia salons and spas in Indonesia. So far, the Majelis Ulama Indonesia (MUI) has not issued a special fatwa and sharia certification for the operation of sharia salons and spas, but many spas and salons are getting halal certification for its products.

Malang is a city in the province of East Java, Indonesia, which has a high potential to develop health tourism, especially with the support of domestic Muslim tourists. The high number of students, especially Muslim ones, poses potential for tourism in Malang. They need to be accommodated and facilitated for health and fitness that meet the values and ethics of sharia, one of which is through sharia spas and salons. There are several sharia salons and spas including RumahQu, YASNA Salon Muslimah, Moz5 Salon Muslimah, and Aliya Salon Spa Muslimah.

Furthermore, in the operation of sharia spa and salon, evaluation and assessment of the effectiveness of marketing and management variables is important to increase the number of users and encourage repeat visits, to increase the income of business, and to help develop the health tourism in Indonesia.

This study attempts to improve the health tourism segments through prospective sharia spas and salons in Malang, in encouraging domestic Muslim tourists. This study aimed to analyze the effect of implementation of sharia services marketing mix that has been applied to decision buying as well as revisit intention in sharia salons and spas.

Originality that this research offers is that it fills the gap of research on prospective sharia salons and spas in extending health tourism using a sharia marketing perspective that is still missing in Indonesia. Abroad, there are only a few researchers like Yemen et al. (2012) in Malaysia, conduct the same study. In Indonesia, previous research on sharia spas and salons is still in early stages of analyzing phenomena and behavior, in a study by Budiyanto (2015). While other researchers analyze the sharia salon spa business from various perspectives such as from the perspective of Islamic architecture in a study by 
Kusjuniardi (2014), Trison (2015), and Indry (2014) as well as from the perspective of human resource management, for example in research by Sari (2013).

\section{LITERATURE REVIEW}

Health Tourism. According to Pendit (1994), there are several types of tourism already known, such as Health Tourism, i.e. one's journey with the aim to exchange the circumstances and the environment in one's everyday live for the sake physical and spiritual health.

Health tourism is a blend of Medical Tourism and Wellness Tourism. Wellness or Healthy Lifestyle Tourism provides improved and preventive health services, and puts more emphasis on relaxation and good look, like beauty, weight loss, and fitness services. Medical tourism provides conventional and traditional medical services such as cosmetic surgery, organ transplantation, chemotherapy, physiotherapy, massage, and acupuncture.

Sharia Marketing. Alom and Haque (2011) state that sharia marketing can be defined as a process and strategy (hikmah) to meet the need through the halal products and services (tayyibat) by mutual consent and welfare (Falah) of both parties of buyer and seller to achieve material and the spiritual wealth in the world and the hereafter.

Sharia Service Marketing Mix. Traditionally, marketing pillars are known as the 4Ps, which stands for Product, Price, Place, and Promotion. However, the three 'P', written especially for the service industry, namely People, Process, and Physical Evidence. Nowadays, the term is known as 7Ps marketing and is sometimes referred to as the services marketing mix (Lovelock, 2011) which consists of Product, Place, Price, Promotion, Process, Physical Evidence, and People.

Furthermore, the marketing concept of Islam could be significant if it is combined with modern marketing concept (Arham, 2010). In a marketing perspective of Islam, the results of study by Wilson (2012) developed Hashim and Hamzah (2014) added 7P marketing from the perspective of Islam by forming Sharia Services Marketing Mix (7P's Sharia Services Marketing Mix) with additional elements, namely Pragmatism, Pertinence, Palliation, Peersupport, Pedagogy, Persistence, and Patience.

Decision Buying. Decision buying according to Kotler and Armstrong (2001) can be interpreted as a decision taken by a prospective buyer regarding the certainty to buy a product or not. Decision Buying Model is developed by Kotler and Amrstrong (2001) which is supported by Kotler et al. (2002), Kotler and Keller (2006), and as well as becomes a dimension of decision for customers to using the services in this study, namely product choice, brand choice, dealer choice, purchase timing, and purchase amount.

Repurchase Intention. According to Schiffman and Kanuk (2008), purchases made by consumers consist of several types, namely purchase interest, purchase trial, repurchase, and repurchase interest. Some of the indicators used to measure interest in revisit are the ones in Repurchase Intention Model based on research by Hellier, Geursen, Carr, and Rickard (2003). The model is developed for this study, in which the indicators are repurchase intention at the same amount, repurchase intention by increasing the amount, and repurchase intention by increasing frequency or intensity.

The Effect of Sharia Services Marketing Mix and Decision Buying (Visiting). Kotler (2005) and supported by Kotler and Armstrong (2008) developed a model of consumer buying behavior indicating that marketing stimulus consisting of product, price, place, and promotion may affect the response of the buyers in the form of purchasing the product.

Empirically, the results of study by Azzadina and Huda (2012) support this theoretical opinion. Research conducted using fashion industry in Bandung, Indonesia with customers of fashion items as samples of the study reveal that there is a significant and positive effect of the marketing mix by management on purchasing decisions.

The Effect of Sharia Services Marketing Mix and Repurchase Intention. Assael (2002) argues that one of the factors influencing repurchase intention of consumers is the marketing stimulus. This, according to Kotler (2005) and Kotler and Armstrong (2008) consists of the marketing mix. Furthermore, Payne (2001) states that to increase repurchase interest, we 
have to note the four key components of marketing i.e. the product, price, place, and promotion. This is in line with the results of research by Alaika (2014) conducted in the child clinic in Bekasi using patients' parents as research sample; the study found that marketing mix made by the management has brought significant and positive impact on the interest of elderly patients for retreatment.

These results are also supported by the results of research by Vahdati (2014) using the 390 customers of Ghaem Shahr Refah Bank in Tehan, Iran as respondents. The results of the study found that the marketing mix brings significant and positive impact on the interest of customers to continue to use the products of the bank.

\section{RESEARCH METHODS}

Sample and Data Collection. This explanatory research uses quantitative research paradigm.

Table 1 - Variables, Dimensions, and Indicators of the Study

\begin{tabular}{|c|c|c|c|}
\hline No. & Variable & Dimension & Indicators \\
\hline \multirow{7}{*}{1} & \multirow{7}{*}{$\begin{array}{l}\text { Sharia } \\
\text { Services } \\
\text { Marketing } \\
\text { Mix (X1) }\end{array}$} & $\begin{array}{l}\text { Pragmatism and } \\
\text { Product }\end{array}$ & $\begin{array}{l}\text { 1. Selling products or services needed } \\
\text { 2. Not selling products or services needed } \\
\text { 3. Separating product or services based on quality }\end{array}$ \\
\hline & & $\begin{array}{l}\text { Persistence and } \\
\text { Promotion }\end{array}$ & $\begin{array}{l}\text { 1. Giving the right information } \\
\text { 2. Education on the products or services } \\
\text { 3. Not exaggerating the quality of the products or services }\end{array}$ \\
\hline & & Palliation and Price & $\begin{array}{l}\text { 1. Giving discount } \\
\text { 2. Selling products or services at reasonable prices } \\
\text { 3. Selling products or services based on sales volume }\end{array}$ \\
\hline & & Peer Support & $\begin{array}{l}\text { 1. Treating customers well } \\
\text { 2. Showing good and ethical behavior to customers }\end{array}$ \\
\hline & & $\begin{array}{l}\text { Pedagogy and } \\
\text { Physical Environment }\end{array}$ & $\begin{array}{l}\text { 1. Having environment ensuring good name } \\
\text { 2. Having environment ensuring good image }\end{array}$ \\
\hline & & $\begin{array}{l}\text { Persistence and } \\
\text { Process }\end{array}$ & $\begin{array}{l}\text { 1. Giving good first impression } \\
\text { 2. Having a mutual agreement on the sale and purchase }\end{array}$ \\
\hline & & Patience and Place & $\begin{array}{l}\text { 1. Being transparent during transactions } \\
\text { 2. Selling real products or services } \\
\text { 3. Having the principle "first come first serve" }\end{array}$ \\
\hline \multirow{5}{*}{2} & \multirow{5}{*}{$\begin{array}{l}\text { Decision } \\
\text { Buying (Y1) }\end{array}$} & Product choice & $\begin{array}{ll}\text { 1. } & \text { Main advantages } \\
\text { 2. } & \text { Quality } \\
\text { 3. } & \text { Guarantee } \\
\text { 4. } & \text { Appearance } \\
\text { 5. } & \text { Features } \\
\text { 6. } & \text { Variations } \\
\end{array}$ \\
\hline & & Brand choice & $\begin{array}{ll}\text { 1. } & \text { Good reputation } \\
\text { 2. } & \text { Well-known } \\
\text { 3. } & \text { Attribute } \\
\end{array}$ \\
\hline & & Dealer choice & $\begin{array}{ll}\text { 1. } & \text { Ease of access } \\
\text { 2. } & \text { Affordable price } \\
\text { 3. } & \text { Complete stock } \\
\text { 4. } & \text { Number and types of agent } \\
\text { 5. } & \text { Products are widely available } \\
\text { 6. } & \text { Marketing facility } \\
\text { 7. } & \text { Promotion } \\
\text { 8. } & \text { Market information } \\
\end{array}$ \\
\hline & & Purchase timing & $\begin{array}{l}\text { 1. Frequent purchase is done } \\
\text { 2. Purchase is habitual } \\
\text { 3. Purchase is repetitive }\end{array}$ \\
\hline & & Purchase amount & $\begin{array}{l}\text { 1. Purchase is in certain amount } \\
\text { 2. Purchase is done to recommend other parties } \\
\text { 3. Purchase is done to improve frequency }\end{array}$ \\
\hline 3 & $\begin{array}{l}\text { Repurchasin } \\
\text { g intention } \\
\text { (Y2) }\end{array}$ & & $\begin{array}{l}\text { 1. Interest to buy at the same amount } \\
\text { 2. Interest to buy by increasing amount } \\
\text { 3. Interest to buy by increasing intensity }\end{array}$ \\
\hline
\end{tabular}


The sample in this study was 150 domestic Muslim tourists visiting the sharia salons and spas in Malang, namely RumahQu, YASNA Salon Muslimah, Moz5 Salon Muslimah, and Aliya Salon Spa Muslimah. The data was collected for approximately 4 weeks from March 2016 until May 2016.

Furthermore, this study used a survey method using a questionnaire. This research was conducted by distributing questionnaires to domestic Muslim tourists as visitors the sharia salons and spas in Malang. Respondents were identified based on age, occupation, average personal income per month, information about the company, domicile, and the reason for visit. Inferential statistical analysis technique used in this study to test the hypothesis of the study was Multiple Regression with SPSS.

Measurement on the Variable. The independent variable in this study is Sharia Services Marketing Mix (X1), while the dependent variables in this study are Decision using (Y1) and Repurchasing intention (Y2) with dimensions and indicators as shown in Table 1.

\section{RESULTS AND DISCUSSION}

Results of Multiple Linear Regression Analysis. The results of multiple regression analysis of independent variables namely Sharia Services Marketing (X1) to the dependent variable of Decision using (Y1) and Repurchasing intention (Y2) can be seen in Table 2.

Table 2 - Results of Multiple Linear Regression Analysis X1 toward $\mathrm{Y} 1$ and $\mathrm{Y} 2$

\begin{tabular}{|c|c|c|c|c|}
\hline Variable & Unstandardized Coefficients & t count & Sig. & Note \\
\hline (Constant) & 3.277 & & & \\
\hline $\mathrm{X} 1$ & .183 & 3.032 & 0.042 & Significant \\
\hline $\mathrm{Y} 1$ & .118 & 3.246 & 0.003 & Significant \\
\hline $\mathrm{Y} 2$ & .102 & 3.051 & 0.001 & Significant \\
\hline $\mathrm{R}$ & $=0.448$ & & \\
$\mathrm{R}$ square & $=0.326$ & & \\
$\mathrm{~F}$ count & $=8.372$ \\
Sig. F & $=0.000$ \\
$\mathrm{~A}$ & $=0.05$
\end{tabular}

Source: Primary Data (processed).

Based on Table 2, the coefficient of determination $\left(R^{2}\right)$ is equal to 0.326 which means that the model on the influence of variables can to explain the perceived value by $32.6 \%$, while the rest is explained by other variables not included in this regression model. The dependent variable of decision buying (Y1) and repurchasing intention (Y2) has a value of $F$ of 7.429 with a significance of $F 0.000$. Thus, it can be concluded that the independent variable of sharia services marketing simultaneously has a significant effect on decision buying (Y1) and repurchasing intention (Y2).

Hypothesis Testing. To test whether the independent variable individually has a significant effect on the dependent variables, $t$-test was used. Below is a table that shows the results of the t-test and t-table at significance level $(\alpha)$ of $5 \%$.

Table 3 - The Results of Hypothesis Testing

\begin{tabular}{|l|l|c|c|}
\hline No & \multicolumn{1}{|c|}{ Hypothesis } & Value & Status \\
\hline \multirow{2}{*}{1.} & $\begin{array}{l}\text { Sharia services marketing (X1) significantly affect the decision to use } \\
\text { sharia services (Y1) }\end{array}$ & $\begin{array}{c}\text { Sig } \mathrm{t}= \\
0,003\end{array}$ & $\begin{array}{c}\mathrm{H} 1 \\
\text { accepted }\end{array}$ \\
\hline \multirow{2}{*}{2.} & $\begin{array}{l}\text { Sharia services marketing (X1) significantly affect the intention to reuse } \\
\text { sharia services (Y2) }\end{array}$ & $\begin{array}{c}\text { Sig } \mathrm{t}= \\
0,001\end{array}$ & $\begin{array}{c}\mathrm{H} 2 \\
\text { accepted }\end{array}$ \\
\hline
\end{tabular}

Source: primary data (processed).

From the hypothesis testing results, it is clear that the two hypotheses are accepted. 


\section{DISCUSSION OF RESULTS}

Hypothesis testing results of this study indicate that the implementation of sharia services marketing affects decision buying and repurchase intention. A more detailed elaboration is as follows:

Sharia Services Marketing Mix Significantly Affect Decision Buying (Visiting). The results of this study indicate that sharia services marketing have a significant effect on customer decisions to use the services. The relationship between the two variables is positive, and the better the sharia services marketing, the higher the interest to use the services. The results showed that pragmatism and products, persistence and promotion, palliation and price, peer support, pedagogy and physical environment, persistence and process, patience and place as constituent of sharia services marketing support product choice, brand choice, dealer choice, purchase timing, and purchase amount as the constituents of decision buying. These results support the idea by Kotler (2005) and Kotler and Armstrong (2008) in a model of consumer purchase behavior and empirically, the results of this study support the research by Azzadina and Huda (2012).

Sharia Services Marketing Mix Significantly Affect Repurchase Intention. The results of this study indicate that Sharia Services Marketing have significant effect on revisiting (repurchasing) interest. The relationship between the two variables is positive, and the better the sharia services marketing, the higher the interest to reuse the services. The results showed that pragmatism and products, persistence and promotion, palliation and price, peer support, pedagogy and physical environment, persistence and process, patience and place as constituent of sharia services marketing support repurchase (revisiting) interest whose constituents are repurchase intention at the same amount, repurchase intention by increasing the amount, and repurchase intention by increasing frequency or intensity.

The results of this study support the idea by Assael (2002) finding the factors that influence repurchase intention of consumers, one of which is marketing stimulus, and Payne (2001) stating that in order to increase interest in the purchase, there are four key components of marketing, namely product, price, place, and promotion that must be met. In addition, the study also supports the results of study by Alaika (2014) and Vahdati (2014).

\section{CONCLUSION}

In general, sharia salons and spas can be an important stimulus and potential for health tourism in Indonesia. Sharia salons and spas can synergize with other health tourism products to improve the performance of health tourism. It should be underlined, based on the results of this study, the application of sharia services marketing support decision to use sharia services and repurchase interest. Therefore, the company should continue to pay attention to human resources, price, interior, composition of raw materials, services, and facilities, as to make them remain consistent with the values of Islamic law. If it can be constantly improved and pursued widely in sharia salons and spas then health tourism in Indonesia will increase massively due to the large number of new visits and revisits of tourists.

Moreover, based on the results of the research, generally domestic Muslim tourists subscribing to sharia salons and spas are young and productive, are not working, are school and college students, are not married, live in boarding house, have relatively limited amount of money, and want treatment for health reasons. Then, the company should implement a program of treatments relatively at affordable costs, to stimulate short-term purchases such as discounts or special packages, to increase the types of treatments for relaxation such as sauna, spa, massage, and aromatherapy, but retain Islamic guidance.

Respondents of this study are still limited to the domestic Muslim tourists visiting sharia salons and spas. Further research can dig on the perspective of foreign tourists. In addition, the research is only focusing on the prospective sharia salons and spas. Further research can use more health tourism objects such as yoga business, mud baths, cosmetic surgery, acupuncture and acupressure, and other health tourism. 


\section{REFERENCES}

1. Alaika, Ilma Arsala (2014) factor-faktor bauran pemasaran yang berhubungan dengan minat kunjungan ulang pasien RS Hermina Bekasi Tahun 2014, Skripsi, Program Studi Kesehatan Masyarakat, UIN Syarif Hidayatullah Jakarta, Jakarta

2. Alom, M. M., \& Haque, M. S. (2011). Marketing: an Islamic perspective. World Journal of Social Sciences, 1(3), 71-81.

3. Assael, H. 2002. Consumer Behavior and Marketing Action. Fifth Edition. Cincinnati Ohio: South-Western College Publishing.

4. Azzadina, Irna and Huda, Aulia Nurul, (2012), Corinthias Pamatang Morgana Sianipar Understanding Relationship between Personality Types, Marketing-mix Factors, and Purchasing Decisions, Procedia - Social and Behavioral Sciences 65, 352 - 357

5. Budiyoanto, Ary (2015), Consuming Islamic Images. The politics of contemporary Indonesian Islamic Culture Industry, Universitas Gadja Mada, Yogyakarta, Indonesia.

6. Cortez, N (2008), Patient without Borders: The Emerging Global Market for Patients and the Evolution of Modern Health Care. Indiana Law Journal, 83:7

7. Henama, Unathi Sonwabile (2014), "Health tourism in South Africa: opportunities and possibilities" African Journal of Hospitality, Tourism and Leisure, 3(1):1-8

8. Herrick, Devon (2007) Medical Tourism: Global Competition in Health Care, NCPA Policy Report No. 304, National Center for Policy Analysis: Dallas, Texas

9. Kotler, P. (2009). Manajemen Pemasaran. Jakarta: P. Airlangga.

10. Kotler, Philip dan Keller, K.L. (2006). Manajemen Pemasaran. Alih Bahasa Benyamin Molan, Ed. 12, Jilid 2. Jakarta: Penerbit PT Indeks

11. Kotler, Philip., dan Armstrong, G. (2001). Prinsip-Prinsip Pemasaran, Jilid 1, Alih Bahasa Imam Nurmawan, Jakarta: Erlangga

12. Kusjuniardi, Mutiara Yudinda (2014), Salon Khusus Wanita Muslimah dengan Interior yang Bernuansakan Timur Tengah, Studi Kasus: Salon Moz5 Surabaya, Skripsi, Jurusan Desain Produk Industri, FTSP, Institut Teknologi Surabaya, Surabaya.

13. Lovelock, C., Wirtz, J (2011). 2nd Edition. Essentials of Services Marketing. Singapore: Prentice Hall. Marketing, Vol. 3, pp. 212-216.

14. MacReady, N (2007), Developing countries court medical tourists. Lancet, 369:18491850.

15. Munro, Julie W (2012) Best Practices in Medical Tourism \#3: What is Medical Tourism? Medical Travel Quality Assurance (MTQUA), Bangkok, Thailand.

16. Narendran, R. (2011). Are the female entrepreneurs of beauty salons in India, victims of bad publicity? International Journal of Diversity in Organizations, Communities and Nations, 11 (1), 47-56.

17. Payne, Adrian. 2001. The Essence of Service Marketing. Diterjemahkan oleh: Fandy Ciptono. Penerbit Andi. Yogyakarta.

18. Pendit, I Nyoman, S. 1994. Ilmu Pariwisata Sebuah Pengantar Perdana. Jakarta: Pradnya Paramita. Sari, Dian Permata (2013) Standar Kinerja Karyawan Azzahra Salon dan Spa Muslimah Yogyakarta, Skripsi, Fakultas Dakwah, Universitas Islam Negeri Sunan Kalijaga Yogyakarta

19. Schiffman. G, Leon, Leslie, Lazar, Kanuk (2008). Perilaku Konsumen. Alih Bahasa Zoelkifli Kasip. Jakarta: Gramedia

20. Tilaar, Martha (2011), Pioneers in Science, Jakarta: Dian Rakyat

21. Trison, Sonia Yulia (2015), Bogor Az-Zikra Sharia Beauty Care and Fitness Center, Publikasi Ilmiah, Program Studi Arsitektur Fakultas Teknik, Universitas Muhammadiyah Surakarta

22. Vahdati , H. et al (2014), A Study on the Effect of Marketing Mix on the Repurchase Intention with the Consideration of the Mediating Role of Brand Equity (Case Study: Ghaem Shahr Refah Bank), Advances in Environmental Biology, 8(21):467-474.

23. Yaman, R. et al (2012) "Beauty Treatment and Spa Design from Islamic Perspective", Procedia - Social and Behavioral Sciences 50:492-501.

24. Young, G. (1973). Tourism - Blessing or Blight?. London: Penguin. 